\title{
Corruption as an organizational process: Understanding the logic of the denormalization of corruption
}

\author{
Corrupción como proceso organizacional: comprendiendo la lógica \\ de la desnormalización de la corrupción \\ David Arellano Gault
}

Centro de Investigación y Docencia Económicas, Mexico

Received 7 April 2015; accepted 14 January 2016

Available online 16 May 2017

\begin{abstract}
This article discusses the basic assumptions of an individualist vision on corruption. A different argument based on "social density" of the phenomenon is proposed instead: the process of normalization of corruption. Under this umbrella, corruption is a political concept that looks to impose a particular vision on what are "right" behaviors based on a sharp and unrealistic separation of the public and private sphere. A review of the organizational literature on corruption is developed, with the aim of understanding how organizational processes of socialization triggers behaviors that make corrupt acts to appear as "normal" under the organizational logic. Persons find themselves in a "slippery slope", generating agreements and social dynamics that are able to produce corrupt logics under the normal life of an organization. A plea for discussing the social processes needed to "un-normalize" corruption is defended a conceptualization that goes beyond an individualist and moralist vision of the phenomenon.

(C) 2017 Universidad Nacional Autónoma de México, Facultad de Contaduría y Administración. This is an open access article under the CC BY-NC-ND license (http://creativecommons.org/licenses/by-nc-nd/4.0/).
\end{abstract}

JEL classification: $\mathrm{M} 48 ; \mathrm{K} 42 ; \mathrm{Z} 13$

Keywords: Corruption; Organizational corruption; Socialization; Rationalization; Strategies against corruption

\section{Resumen}

El artículo cuestiona los supuestos de la visión individualista de la corrupción y se introduce al contrario una conceptualización más «densa socialmente»: el proceso de normalización de la corrupción. En esta

E-mail address: david.arellano@cide.edu

Peer review under the responsibility of Universidad Nacional Autónoma de México. 
última lógica, se advierte que una definición de corrupción es siempre una definición política e ideológica que intenta imponer una visión determinada de comportamientos «adecuados» de acuerdo a una separación pretendidamente tajante y clara entre las esferas de lo público y lo privado. Se realiza una revisión de parte de la literatura sobre corrupción organizacional, con el fin de comprender cómo las rutinas, procesos y estructuras de socialización propias de la arena organizacional pueden llevar justamente a las personas a «caer en resbaladilla» hacia una dinámica de corrupción. A normalizarla en otras palabras. Se concluye con un llamado a discutir los procesos de desnormalización de la corrupción, como estrategia sustantiva más allá de la visión individualista o moralista del fenómeno.

(C) 2017 Universidad Nacional Autónoma de México, Facultad de Contaduría y Administración. Este es un artículo Open Access bajo la licencia CC BY-NC-ND (http://creativecommons.org/licenses/by-nc-nd/4.0/).

Códigos JEL: M48; K42; Z13

Palabras clave: Corrupción; Corrupción organizacional; Socialización; Racionalización; Estrategias contra la corrupción

\section{Introduction}

It is common, in the literature on corruption (e.g., Nye, 1967; Rose-Ackerman, 1978) to define it as an act of an individual, an inappropriate or deviated act according to certain parameters or social values that are relatively accepted in a society or group. This definition even opens the possibility to understand that, beyond the inappropriateness of the behavior of the person, it could be considered, under certain circumstances, as a rational or calculated behavior. In other words, corruption, from this analytical angle, is the decision made by an individual during a transaction with another individual or group of individuals, (unduly) taking advantage of from a specific position in this relation or transaction. This individualistic vision is sustained on a starting point: that the individual knows or understands in a broad manner, the situation in which she is and has calculated that behaving corruptly is convenient or beneficial to her. This way, a very particular interaction model is formed between actors that consciously calculate and act, measuring the consequences with a certain logic and intention. In this way, when placing emphasis in calculating individuals that act substantively thanks to this calculation ability (i.e., based on a conscious behavior), corruption is seen as a decision made by individuals under a certain and particular value context. In this logic of conscious and calculating individuals we can infer several things: first, that corruption is inevitable in social relations, as it is funded in the calculations of rational actors. Second, fighting it is basically a matter of affecting the balance between cost and benefit that the individuals are able to calculate.

The main issue to be considered in this article is that this individualistic vision is incredibly limited, first, to understand the phenomenon in its entirety and therefore, as a second point, to propose long-term solutions. The main objective of this document is to demonstrate, through a review of the literature on organizational corruption, that corruption is not a phenomenon where individuals enter discreet relations, but rather a dense social phenomenon. It is a social relation, in other words. And this social logic is both true for corruption in the private sector as it is in the public one, thus this article does not make a particular distinction between them. In other words, we speak of corruption in organizations of any type. From the review of this organizational literature of corruption we seek to fairly identify how corruption may be normalized as a social process with stages and socialization processes and rationalization.

The way in which the argument is developed is by analyzing how the studies of organizational corruption place significant emphasis in the group and social space where the decision is made and where the behavior generates. In this manner, we arrive to very different diagnoses and 
conclusions, which a lot of the time are counterintuitive with regard to the individualistic vision. The point of departure is therefore that corruption is generated and thrives in the world of social relations, where the individuals, their agency, their behavior, are closely linked and affected by the interactions and context where they play and build their own image, their own will (de Graff, 2007). The behavior is a product that is rational, emotional and relational (Chugh, Bazerman, \& Banaji, 2005, p. 79), where the interactions and rules and structures within which the people behave do matter. In this article, we will follow the perspective of Chibnall and Saunders where corruption is seen as a "negotiated classification of a behavior before an inherent quality on the behavior itself" (1977, p. 139). In other words, the concept of corruption is a very particular social construct of a society that, in its imaginary standards, has tried to separate the private from the public in the clearest and strictest way possible. Only this way is it feasible to find definitions that establish that corruption is, for example, the abuse of an organizational position to illegitimately gain benefits (Ananad et al., 2004, p. 40). This classic definition implicitly speaks of a clear differentiation of the private benefit over the collective or group benefit; it is a permanent essence of the different contemporary definitions of corruption. ${ }^{1}$

To discuss the huge social and normative burden that the classic definitions of corruption have, the following is important. Stating that corruption is a wrongful act, requires to define the following: for whom is it wrongful? In what context A vision based on the idea of "wrongful" implies that there is an external, clear, legit parameter that surrounds an individual and a group, which clearly marks with relative clarity what makes a behavior correct or corrupt. Even if this does sound reasonable and easy to understand, it is not really so in practice. For example, if the definition is so clear on what is wrongful then it should be clear on the contrary as well: how can you define a no-corruption state? (Philp, 1997). To answer such question is no easy task, therefore, we've tried to form definitions that are not of the corruption phenomenon as it is, but of some of its characteristics. People have attempted to generate clear distinctions on what acts of legitimate benefit means, for example (using political strategies to rise to higher levels in the organization in order to earn more money and prestige is legitimate, but helping a relative into the organization is not). A person can suspect being in a conflict of interest; for example, if they had a friend for several years and now, in a new position, it could negatively affect their judgment. Socially speaking, conceptual negotiation would imply that the person evaluates these possibilities in at least three complex steps: first, if the friendship has the power to influence, second, if said influence could clearly be illegitimate or only improper (to the eyes of certain actors), and third, define what the consequences of such influence could be. Each step implies a profound reflection and understanding of the context of the situation on behalf of the actor. This makes it possible to propose that all definitions of corruption are, in essence, fighting to negotiate a classification of behaviors, suspecting that that classification explains the nature of the phenomenon.

In the same manner, a corrupt group or organizational context could be implemented before the arrival of a certain person to the organization. The corrupt social relation could be installed so it has become normalized (Bratsis, 2003, p. 17), it could even be an instituted rule for the integration of the group. In the case of organizations therefore, a corrupt act may be seen as corruption by an

\footnotetext{
1 Andersson and Heywood (2009, p. 749) state that the attempt to create a global definition of corruption will have to face, no matter what, the variability of the situations and types of corruption: depending on whether we are talking about the public or the private sector, of an administrative or political process; of the actors involved, be they public or private servants, businessmen, citizens; of the gravity and the scope of the acts (sporadic, systemic, severe or mere violations). We would add to these variations, those that are caused by the organizational dynamics that we study in this document.
} 
external group under certain parameters, but those within may think the same act as a normal or non-corrupt act.

The person is embedded in social spaces such as the organizations, and in this sense, the group logic imposes a series of possibilities and conditions on the way people handle and present themselves in such social spaces. There is, for instance, important literature on the anthropologic, cultural and discursive logic of corruption (Andersson \& Heywood, 2009; Graaf, Wagenaar and Hoenderboom, 2010, p. 99; Haller and Shore, 2005; Sissaner, 2001). The secrecy in an organization, for instance, has to do with the conventions that regulate certain groups, who knows what, what information they possess and why (Costas and Grey, 2014, p. 10). The rules and the norms, formal and informal, of the group or groups, establish this "normality" of relations that could only be seen as "strange" under the light of an external code of reference that establishes that this secrecy could be a source of corruption. The social density of the corruption brings to the front the analysis of arguments, even counterintuitive ones, such as those that state that the people accused of corruption could argue that they did not know that what they were doing was wrong.

This article has a specific method: perform a review of the organizational literature on corruption which is little-known in the field of debate on this topic. This method has the advantage of introducing a series of concepts and discussions that have been debated very little in the dominant debate spaces on corruption, more prone to normative and instrumental debates. This chosen method has, however, some disadvantages: the main one being the lack of specific empirical studies. We have developed some of these studies in other places (Arellano, 2012). However, we hope that this article boosts the interest in making more empirical studies, especially for the case of corruption in Mexico and Latin America.

That said, from the review of the literature on organizational corruption, the article establishes that it is necessary, if we want to fight corruption in an organization or group of organizations, to relativize the strategies that see it as a problem of individuals calculating costs and benefits. Seen as a dense social phenomenon, a product of social relations, corruption is a point of arrival and not of departure. For an actor with this logic, to classify and understand a specific act, and to be able to differentiate it as an honest or dishonest act implies that the person would have to compare it against the agreements and practices established, as a group, as normal in their daily practice. Denormalizing corruption seems to be the center of a strategy that completely understands this collective construction of the phenomenon and of the acts that comprise it.

The article comprises five sections including this introduction. In Section 2 we discuss the organization as a social process that forms behaviors in a web of rules, senses and norms that generate the organizational "normality". This normality built in the space where, in the search to make sense of people's behavior, the organizations create social interaction processes that attempt to socialize people in their dynamics, including those that could be considered as corrupt (Section 3). Sure enough, it may seem counterintuitive but the socialization process also works for events such as corruption, where people rationalize their acts by giving them a sense within an organizational scheme. This rationalization allows people to reduce their cognitive dissonance, meaning, the sense of angst before the probability of doing a wrongful act (through certain internal or external patterns to the organization). In the fourth section we explain how these rationalization and socialization processes can therefore constitute a stable dynamic in time, one that builds a certain plot of relations that reinforce each other, establishing a species of "slide" where more and more people, more frequently fall or are trapped in corrupt networks. They are not rationalized and become a part of the organizational scheme as normal behavior, but they also become generalized. And in that moment it is possible to speak of an organization that has turned corruption into a normal and justified act (it has normalized acts that seen in other contexts or by other actors can 
be classified as corrupt acts). In the last section we present some conclusions regarding the impact that the argument of corruption normalization can have on the strategies to fight this phenomenon that is a focus of attention and concern among society.

\section{Organizations with corrupt individuals or corrupt organizations?}

The reasons why an individual carries out dishonest actions are several and diverse. Corruption is in fact a social phenomenon: an individual chooses to be corrupt or carries out a dishonest action (we will see that there is a difference between the two) always in a context where their psychological relations, experiences, values and the social interactions that they live and constantly suffer, become a part of the equation (Rest, 1986).

Berger and Luckmann (1978) are very clear regarding how every human interaction starts, becomes and is defined within a social logic: interactions create bonds between people. Bonds that can last a second or decades. Bonds that are capable of eventually creating groups and subgroups that share objectives or beliefs. These bonds can also be seen as socialization dynamics, meaning, self-organization dynamics (Goffman, 1983): once bonds have been created, they tend to become more stable and are able to reproduce to other people as they communicate and share, e.g., through routines. In this context, socialization implies the creation and re-creation of perceptions and eventually behaviors that the individuals induce, understand and generate in order to take the relationship between them to a (or several) different context, according to the perspective of each agent involved.

The socialization process, being situational and contingent at the core (depending on the specific persons and situations in which they are) comprises stabilizing elements, but that are ultimately changing and modifiable. Due to this, socialization mechanisms may be contradictory, obscure, and counterintuitive. Agency and structure (Giddens, 1984, p. 5) are merely interpreted, thus there is no guarantee that the socialization processes are able to escape the interaction dynamics. In other words, socialization processes can generate several different reactions from the different agents and they can also create unexpected effects that could be counterintuitive for the actors involved. This is what usually happens in those organizations that fall for the logic of corruption: they have socialized practices and behaviors that induce people to corruption, a lot of the time as an unexpected and undesired consequence.

Following this line of thought, we can understand how in a specific organizational framework, the definition of what a dishonest behavior is, is linked to a classification and structure within what is organizationally defined: a behavior is classified by some and in certain circumstances as such because it violates certain organizational (or group) standards that are generally accepted (all of this does not necessarily mean that this agreement is unanimous or that it is the same for everyone; Kish-Gephart, Harrison, \& Treviño, 2010, p. 2). ${ }^{2}$ The cases being discussed are

\footnotetext{
2 The density of the phenomenon of corruption, seen from an organizational point of view, makes its understanding even more complex. For example, it would be necessary to differentiate a corrupt act form other very similar acts, such as inappropriate behavior (e.g., harassment at the workplace), deviated organizational behavior (pretending to be working, for example) or anti-social behavior (e.g. bullying) (Ackroyd and Thompson, 1999). Boundaries are not rigid, of course, as organizational processes, the three previous behaviors could lead to a corrupt act. Some authors differentiate it with the obtainment of a financial gain. This would imply that the organizational corruption of individuals could go from bribery, financial disguise, over-estimation of expenses or working hours, fraud, and even robbery. Organizational corruption for the benefit of the organization would be corporate fraud, business crime and deviation of the business toward criminal activities.
} 
therefore multiplied: people that defend what they did not know were corrupt acts, acts that in a particular context are defined as corrupt and in another are not, acts that are temporarily seen as acceptable but that given certain circumstances stop being so.

It is important to study and understand how sense and socialization are organizationally formed, especially if we are discussing the normalization of acts such as corruption. We can start by establishing that the organizations can be seen as social creatures comprised by people who behave a certain way (Simon, Thompson, \& Smithburg, 2010 [1950]: 55). This behavior is based on the combination of the burdens and individual situations of each participant and on the relationships that the person has with other people, in a framework with a level of formality and a certain degree of domination that pretends to unite these relationships with a particular aim, and in a framework that comprises a degree of "normality" and what is "acceptable". At any rate, in the organized framework, people socialize their thoughts and intentions within a not so rigid framework but that does comprise behaviors aimed to a certain objective and with certain premises. This is why people comprise organizations, but organizations are more than just the people that comprise them: they become a series of relations between people, social, group and individual bonds, incidental but that become stable over time.

In this manner, when speaking of corruption, it is almost impossible not to speak of organization. Corrupter and corrupted, corrupt people and victims, they are sooner or later found within the framework of the organizations that regulate, monitor, encourage or attempt to control them. Therefore, trying to understand how corruption is generated is to attempt to understand the dynamic of the bonds and relationships (temporal or semi-permanent) that are built between the different agents so that this practice is possible to be carried out and even to stabilize (as the systemic corruption idea insinuates).

When introducing the organizational variable, the psychological and group elements of corruption appear with clarity and without any moralistic tones. This in the tradition of Goffman who tried to "read" the presentation processes between people, such as the logical acts, including the machination and settling of the façade used to present themselves in a group reunion within the organization. For example, the hiding and deceit process that tends to lead organizations to systematize corruption acts is not generated in one act alone, but it develops from a non-detected lie to bigger lies to support the original lie (Messick \& Bazerman, 1996, p. 21). It is hard for a lie or a deceitful action to be an individual activity in an organization: deceitful actions involve more and more people little by little: coworkers and even authorities could start to put pressure in order to maintain the network of lies (Cialdini, Pterova, \& Goldstein, 2004, p. 70-71). The language can change, the organizational agents change the words to avoid making them seem like lies or questionable facts, rather to make them more "hygienic" (e.g. instead of speaking about bribery use phrases like "grease the machinery", Bandura, 1990). These elements, in the end, give evidence on how the lies and deceit can begin in a reduced dimension, grow and then get tangled in the network of personal and hierarchical relations, falling, little by little, as if on a slide, in social and institutional corrupt dynamics.

Two metaphors have tried to simplify these organizational explanations (unfortunately, sometimes this is done with a moralistic tone): the phenomenon of the "bad apple" or the "bad barrel". One person or a group of people who have decided to be corrupt and ethically violate the organizational rules, become(s) the bad apple. In the case of the bad barrel, we allude to the organization (or one of its structures or parts) that has fallen in a corrupt dynamic that can be hidden in an aura of ethical or rational action. Otherwise explained, corruption vs the organization, or corruption in the name of the organization (Pinto, Leana, \& Pil, 2008, p. 685). The issue in every case seems to be that, beyond labels, it is important to understand how a person can become a bad apple, 
sometimes even without realizing it, and how in this process, the barrel and its dynamic, could be of great importance for such effect. In the following section we will introduce the organizational process of corruption as it has been presented in the previous paragraphs.

\section{The organizational processes of corruption: normalized through rationalization and socialization}

The most counterintuitive organizational characteristic of corruption in organizations is that the acts of corruption become normal. The literature in this regard is full of evidence and references that indicate that, in general, the people that have been processed for corruption deny having done something illegal or amoral (Benson, 1985; Conklin, 1977; Cressey, 1986; Geis and Meier, 1979; Sykes \& Matza, 1957).

One of the possible explanations for this pretend paradox can be found, precisely, in the ability of organizations to routinize and normalize the different activities, values and objectives of the individuals and of the groups that comprise them. The same way an organization normalizes the respect for hierarchy or the acceptable procedures in daily work, these same dynamics seem to work to convert behavior that could be classified as corrupt, into "normal" behavior. Furthermore, a group of non-corrupt behaviors could combine with others that are corrupt, and an individual in particular may not have the whole picture of the interaction between different agents. The people in the organizations need to find the sense of what they do and their perspective is always limited (by time, resources, skill, as the classic concept of limited rationality of Simon, 1947 dictates). Thus, an organization builds a series of influence mechanisms, routines and principles that help the members of the organization make sense of their actions, saving time through routines, promoting cooperation through standardized, specialized and compartmentalized processes. All these, among other mechanisms or influence instruments. It is these same mechanisms which, intentionally or not, are able to build normalization schemes for action networks and corrupt behaviors.

From this starting point, the organizational action is a social construct a la Berger and Luckmann (1978): the organizational actors form different interpretations and loyalties to internalize different socialization logics. The group, the sub-group, the department, the organization as a whole, the industry where the organization thrives, and lastly, the country, the society, are different levels where the actor internalizes and socializes the standards, the rules, the expectations, and even the moral principles, which become a part in that collectivity (Chibnall \& Sauders, 1977, p: 141). Evidently, this secondary socialization as is called by Berger and Luckmann, implies a process that can be contradictory in its interpretation at different levels of aggregation. In short, the socialization logics of one of the layers (e.g., the organization) could clash against another level (e.g., the group). To accuse a colleague of corruption, for example, could be what is more beneficial to the organization as a whole, but morally, it could be seen by the group as an act of disloyalty. To disguise some financial figures could be beneficial for the organization, under the argument that good people made a mistake with good intentions, for example, but it could be seen as an act of corruption at a societal level. How do human beings deal with these fundamental contradictions? A possible answer is just that, through rationalization.

Rationalization is an act of fundamental interpretation and it is crucial so that an actor is able to become a social actor. At least through Goffman (1981) it is well understood that individuals know how to present themselves before others with a fundamental strategy of successes and step backs that allow them to build a certain image and provide an amount of uncertainty to the expected interactions with others. Why obey a boss? Because the legitimacy or hierarchy is believed, as per Weber. It is a necessary rationalization for the formation of the social interaction network. 
This rationalization does not stop being an interpretation, a strategy to provide sense, a patchwork of essence and appearance that the actors wish to be observed and at the same time hope to remain hidden (opacity is a fundamental ingredient of interaction. Arellano, 2010; Costas and Grey, 2014). Not only opacity, but also the secret and secrecy comprise a fundamental part of the repertoire of interaction and communication strategies in organizations (Zerubavel, 2006). When speaking of corruption, for example, the actors in a group within the organization could have already created a rationalization that helps build this act, not as a corrupt act, but as an accident or unnecessary act to achieve a greater good, with the intention of maintaining a certain level of collective moral health that justifies the group (Ashforth \& Anand, 2003, p. 16).

The range of rationalization options in cases of corruption is diverse and broad. Let us summarize what the literature on this topic has found in different experiences and cases (Ananad et al., 2004, Ashforth \& Ananad, 2003; Ashforth, Gioia, Robinson, \& Treviño, 2008; Felps, Mitchell, \& Byington, 2006, Fleming \& Zyglidopoulos, 2009, Kish-Gephart et al., 2010; Pinto et al., 2008; Zyglidopoulos \& Fleming, 2008; Zyglidopoulos, Fleming, \& Rothenberg, 2009).

\section{Rejection of responsibility}

This is the classic displacement that a person can make to establish that they were part of a great machine where they did not have the possibility of understanding that fraud or an act of corruption was taking place. Or argue that they were only following orders or that they were doing what everybody else was doing and therefore, it was a moral act. In any case, it is rationalized that the person had no control over the situation. A transit police officer that is immediately introduced by their superiors and colleagues to the bribery fees to be paid each week, could show signs of this type of normalization.

\section{Damage denial}

The agents that find themselves in these circumstances can argue that in reality the acts for which they are being accuse are of so little importance, compared, for example, with the earnings or benefits of the organization, that it is not reasonable to say that it was theft or an act of corruption. "Pilferage" or the over the counter request of payment "for refreshments" can serve as an example.

\section{Victim denial}

A classic version of this rationalization is to suggest that the receptor of the illegal or dishonest act is even more dishonest, making them deserving of said treatment. That is to say, someone was affected but said person is not a victim, but rather an instance so corrupt or so grand and powerful and unjust, that the act classified as corruption was in fact almost an act of vindication in the face of the injustices. The theft of resources from a union to a large organization that refuses to pay better salaries to its employees can serve as an example of this rationalization.

\section{Social compensation}

This rationalization is strong socially speaking, but common: it implies giving importance or a relative value to the beliefs or needs of others. If there are corrupt and powerful actors, and the laws are considered unjust, then it is rationalized that they can be justified in acting in an apparently dishonest manner, given that in reality "the others" are the ones truly corrupt. Or when 
it is justified that a corrupt act in reality reduces great prejudices toward weak persons (this small bribe prevents worse consequences for a relatively defenseless person). Many of the "small" bribes can follow this logic: the bribe at least helps so others pay less and even prevent that the payment reaches the "truly corrupt".

\section{Higher loyalties}

The different layers of socialization that individuals live lead to contradictions between loyalties to different groups. The esprit de corps can be stronger than loyalties to "greater" logics such as the law or standards. It is a rather contradictory rationalization, but very real: the law is corrupted in the name of justice, making the ends justify the means. A police officer can refuse to accuse another due to this esprit de corps, or use dishonest influences in order to force a guilty verdict in the conviction of an accused.

\section{The metaphor of balance}

This rationalization implies the calculation that can be carried out from the "contributions" of a person that considers them so large that they "deserve" a particular retribution (which sometimes said person has taken illegally). In other words, a bureaucrat can argue that they work many hours, many more than the others, and therefore the pilferage or bribe they requested was justified as compensation in the face of the extra effort given.

Evidently, these rationalizations can be interpreted as simple lies or hypocritical justifications. However, the story is not that simple. Many times, these rationalizations are real interpretation and justification mechanisms, which allow the actor to feel better about themselves, reducing anguish or dissonance between their general values and their particular actions (Gigerenzer, 2002). Denial, in psychology, is not exclusively an act of hypocrisy, but rather a mental and social process of justification and modification of the interpretation parameters on the part of human beings (Bargh Tanya and Chartrand, 1999, p. 475; Lerner \& Tetlock, 1999, p. 263). Self-deception, as counterintuitive as it sounds, is a fundamental reality, widely studied in psychology as an act of modification of the mental parameters in order to evaluate reality (Eagleman, 2012; Lehrer, 2009, Ainslie, 2001). In other words, people build stories and perceptions in such a way to be able to reduce and even eliminate (at least temporarily) the cognitive dissonance or anguish that knowing that they are committing an unduly act produces (Festinger, 1957). Said dissonance is an internal tension of the ideas or emotions of the person with regard to what they observe to be or could be reality. By reducing the dissonance, it is possible to feel less morally affected, for example, in the face of an act carried out under particular circumstances and in specific contexts. A person, thus, can reduce cognitive dissonance if they rationalize that their act of corruption was not so serious, was followed by others, was ordered by others, or if it is part of an act of redistributive "justice" against the "true villains". The main point is that rationalization implies a real and creative effort with impacts effective in the interpretation of the person regarding the honesty or lack thereof of an act. Furthermore, this rationalization can be broadly reinforced through the organization and its groups, in a systematic or implicit form of routines or practices.

\section{Corrupting the organization: socialization or the corruption slippery-slope}

The mental and relational process that makes a corrupt act not be seen or rationalized as such by the people, can be broadly reinforced by the organizational dynamic. Organizations 
are usually seen as instruments or semi-robotic machines where the people are the gears of a well-oiled machine. However, in reality, organizations are social constructs assumed to be formalized, but which build intricate and intense human and social relations in order to direct many people to reach agreements, form groups, internalize behaviors and values, as well as satisfy the achievement of objectives, people who must also interpret and give sense to said objectives (Weick, 2001).

A person that enters an organization begins a dense socialization process. What is the organization? What people comprise it? What groups manage it? What are the prevailing values of hierarchy, obedience, cooperation, conflict and negotiation?..among many other processes that any person is required to decode when entering an organization (Kunda, 1992). These social forces and dynamics that allow people to be introduced and to learn and build their role and function within the organization, work for formalized matters (such as identifying the hierarchy and the rules of communication), as do they for the socialization of actions or behaviors that could, given time, feed corruption. This contraction is one of the most important to understand, as it explains rather clearly why the persons generally accused of corruption do not think themselves guilty of said acts. In other words, we are not speaking only of cynicism or of the calculation of people to deny corruption. Nor only of the psychological process that allows for rationalization as analyzed in the section above. We are also speaking of the very organizational processes that allow a person to be part of the group, of the organization, which act and function in order to place and position the actor in relational plots, and of actors who, in the end, could be classified as corrupt. However, in this case, we speak of acts of corruption which the very organizational processes, paradoxically, helped to cement, consolidate and make them customary.

In this section we will review four classic socialization process of corruption (Milgram [1974] 2005): agentification, cooptation, incrementalism and compromise. These four processes allow, in principle, to understand how the social dynamic of introducing a person to the organizational logic comes about gradually, as a true learning process of the interaction rules and standards in a collective. The preferred metaphor is that of the "slippery-slope": the way the mental and social processes of rationalization are rebuilt and strengthened, little by little, by the organizational logic of interaction. In the case of corruption, the organizations can create conditions so that the people gradually "slide" to commit acts of corruption in a process that facilitates said acts to be rationalized and justified as "normal" or at least acceptable from the logic of the group or even that of the organization. So that this "slide" effect is generated, it is necessary for the person to be incorporated into the rules and traditions or organizational practices, being accepted as an integrated or embedded agent into said rules and practices (further in this document we shall discuss this as agentification). Thanks to this process, the person in the organization continues to be the same individual who entered into it, but at the same time they are a different person: the one who obeys, is accepted, "knows" how to interpret and understands the "culture" or "nature" of the organization as a sub-world where many of their behaviors and feelings only have logic while they are within the organization. ${ }^{3}$

\footnotetext{
3 This behavior that appears counterintuitive, has also been proposed and studied in questions such as evil or outright inhumane acts. Studies on the Nazi physicians (Lifton, 1986), the murder of My Lai (Turse, 2013), among others (Staub, 1989), have argued that what is most disconcerting is not finding intrinsically evil beings developing terrible activities, but rather the opposite: common people trapped in social and organizational forces.
} 


\section{Organizational agentification}

Agentification is the psychological and social process that leads a person to internalize their role within the organization and to observe it and its members with the legitimacy and authority to direct their behavior. In a way it is one of the organizational keys in constructing the other three socialization processes (cooptation, incrementalism, and compromise).

The organizations can be seen as social constructs that try to formalize diverse mechanisms of human interaction with the purpose of achieving certain relatively specified (but never closed) ends. The mechanisms of human interaction are constituted, at least in part, in an intersubjective game of mutual expectations between the agents: someone searches for something that in some manner depends on the reaction of another, thus it intuits that it is required and it depends, in some manner, on the reaction of another. This is the base of interaction that generates social links, invisible but not any less real, which link the agents. These links of human relation are played in various social spaces, many of them in face to face relations (Goffman, 1983). They are links that force many times for an interaction to be illocutionary or dramatized, dependent on their own mask games, secrets and lies (which have been solidly studied in psychology since at least the classic text of Simmel, 1906). The organizations, thus seen, constitute spaces that are intended formalized, thus all these intertwined games exist and are maintained in but a facet that bases their legitimacy in the formalization of the relations. The formal importance is, therefore, not in that it displaces or eliminates "informal" or human face to face or illocutionary logic: what the organization does, in any case, is to give legitimacy to a formal facet such as organizer or strict floor on which the informal game is played. An organization that is seen as legitimate by the people is a strong source of obedience and, therefore, a strong means to direct behaviors toward certain directions. The famous experiment by Milgram ([1974] 2005) confirms how the weight of the authority triggers a series of reactions, thoughts, assumptions and justifications that allow people to rationalize their actions in light of the people and their authority and the rules or standards defended in their name. The "agentic state" (Milgram [1974], 2005, p. 133) is that in which the individual, who can consider themselves as autonomous in certain circumstances, once inside the organization, transforms their behavior and rational to the logic of the order of the organization. According to Milgran, they enter a state that allows for the obedience of the person, something that is very well done by the organizations.

Thus, the agentic organizational person is the person who "knows" how to behave in the organization. To this end, in order to "know" and be accepted, they need to behave in a certain way that many times implies behaviors that appear only while within the organization. The point here is not to plant a dichotomy, as Milgram has sometimes been critiqued of doing (Darley, 2001, p. 207), between the individual as such outside the organization and "another person" who enters an agentic state: in this case we refer, rather, to a series of social and organizational forces that drive and direct the behavior of the people (once more, not as automata, rather, as thinking people in an always moving social scheme).

Authority, obedience, accepted rules and standards, standardization and routine, they are all organizational forces that are capable of driving complex interpretations in people. Thus, the matter that follows is that organizations are a highly important social force that intrinsically, in a relatively normal manner, produce this type of agentic state, which at the same time assures obedience and perseverance for the achievement of objectives, and can, in certain circumstances, produce systematized and standardized corruption. 


\section{Cooptation}

One of the classic steps in which the groups inside the organization induce changes on the people that enter the same is by letting them know the benefits and powers that said person could have by belonging to the formal group (and sometimes informal). Placing said benefits and powers as part of the labor has been known in organizational literature as "collateral payments" (Cyert \& March, 1965). If said collateral payments come about from wrongful activities, they can be introduced little by little as payments that action and cooperation provide even if they are not formalized. It could even be that the person recently introduced is not aware of the possible misappropriation of resources until after some time and after having received said collateral payments in a constant basis. The main point of cooptation is precisely to share interests, earnings and risks. Once a person has been introduced to the red of relations and benefits, it is more difficult for said person to comprehend the implications of their participation in the organizational actions and processes, even those that could be considered wrongful.

\section{Incrementalism}

Diverse studies on corruption in organizations have noted that there is a gradual introduction process of the people to the red of wrongful actions and decisions (Van Gennep, 1960; McLean \& Elkind, 2004). The process can begin by assigning the newly arrived person small tasks, sometimes even insignificant, but that allow them to introduce themselves into the chain of diverse actions that lead to an organizational product or effect. This classic manner of introducing a person to the organization and its processes can be used in turn for wrongful effects. Once more, the person that in the beginning does not understand the moral problematic of the effect of their action until they have already participated in the chain, each time with more responsibilities and probably with a position to now better understand the consequence of their actions. It is also possible that this gradual introduction to the chain of corruption makes it more difficult to leave it. The strength of the past, or of past actions could then fall strongly on the person, making it difficult for him to take the decision of not only leaving but also denouncing (or as it is known in the literature, whistleblowing).

\section{Compromise}

The effective life of a person in an organization is filled with moments in which they must face various types of restrictions, regulatory obligations, and pressure to achieve objectives with certain standards and do so in an organizational life of hierarchies, horizontal relations with others, group links and even friendships or enmities. It is not strange in these circumstances for one or more of these elements to become contradictory. Achieving the objectives with efficiency could imply dismissing people from other groups or from one's own group. Or perhaps flexibly complying with certain rules or even disobeying them outright if it is for the good of the group or the objectives of the organization. For example, achieving results and standards tends to be one of the strongest pressures in the contemporary organizational world. The insistence of taking the results as the only thing that matters, in turbulent and uncertain contexts, impose on the people a series of great pressures and anxieties in the face of the difficulty and uncertainty of achieving said standards or indicators of results (see the experimental studies of Lerner \& Tetlock, 1999). In this manner, an individual can reach the point of accepting flexibilities in relations, rules or processes with the purpose of meeting certain results or avoid certain negative consequences. The 
commitment with the organization, with the group, with the overall objectives, can be forces that make people begin to relax their patterns of adherence to the standards or rules, first in a reduced manner, but later gradually with greater flexibilities each time.

As can be quickly understood, the rationalization and socialization dynamics reinforce each other mutually. When the useful but extremely simple assumption of the individual calculating decision-maker is ignored and both the mental and psychological mechanisms to rationalize and give sense to one's own acts are understood, and they are then introduced into an arena of relations, rules and organizational times, corruption begins to be seen with a much more dynamic perspective. It is also much more worrying as the difficulty that the mechanism that have looked to deal with it have can be deduced. ${ }^{4}$

\section{Conclusions}

The objective of this article has been, from a review of the literature on organizational corruption, to understand the standardizing process of corruption. This process is one that is counterintuitive and that can frustrate many people who would expect to find quick and precise formulas to reduce the phenomenon (some even dream with eliminating it completely). The organizational vision of corruption leaves it clear that there is no such "silver bullet" and that corruption is a social phenomenon of dense relations, where what is "normal" and "abnormal" is negotiated and intersect in the arenas where the agents end up interacting on the day to day.

A society and its organizations can advance in reducing and limiting corruption. They require an interesting social process: analyzing in-depth the practices, routines and rationalizations that define their relations as normal. Understand, in other words, how the "normal" logic in which the people relate in an organization can be generating that very phenomenon of corruption.

The denormalization of corruption is thus a necessary and extremely difficult step to carry out. It is difficult because it implies delving into the social relations, into the processes that made routine a series of behaviors that can even already be found rationalized.

One can begin understanding this denormalization if we accept that corruption is, after all, a social category greatly loaded with values and expectations (Rose-Ackerman, 2014, p 4). The objective of this conclusion is not to discuss or to take a side, for example, with regard to an argument that has been talked about recently (even as extravagant, Caiden, Dwivedi, \& Jabbra, 2001, p 31): that corruption can be an inevitable phenomenon and in some sense even a benefit in the long term socially speaking.

It is clear that, for many people, the aforementioned statement has become important to act with regard to corruption given its negative effects in many countries and contexts. The cases of generalized corruption in governments such as that of Mexico, Brazil, Guatemala (just to mention some that in this decade have gathered public attention) and in companies such as Enron, Petrobras, and Parmalat which have garnered a great deal of social attention as extremely worrying and grave cases. Without a doubt, all of this pushes various analysts to propose solutions, preferably quick and universal solutions. We can even already speak of an anti-corruption community that has acquired its own political dynamic and logic. However, as we have proposed here, the hope that corruption can be eliminated from the social relations is not so simple to accomplish. It is even impossible, if we take to the extreme the argument we have defended here. The organizational vision of corruption is in fact a strong source in understanding why. The agent continues to

\footnotetext{
${ }^{4}$ Even making it further from the nudges, which is not clear, generate a cognitive change (Mols et al., 2014).
} 
be the one that falls in a corrupt logic. However, the individual decision can often be seen in social frameworks such as the organizations (as we have discussed here), and to the individual calculating logic we then add the emotional or motivational logic and the social or of the relations (Chugh et al., 2005, p. 78). Every one of these logics has its own dynamic and the anti-corruption instruments that are considered and implemented will be seen affected in a different manner by each of them. It is probably because of this that the "battle" against corruption is so difficult and produces variable results.

In any case, the acts of corruption are many times a point of arrival more than a discrete decision of an individual auto-controlled actor: the social interaction of people with emotions creates a dynamic, a language, a timing of interaction and action, and a rationalization that allows the actor to justify their action. The social space influences, prepares, and normalizes the action and decisions. More importantly, it normalizes the interpretation to make way for a series of actions which are carried out almost automatically, making for certain acts to be normal. Normal because others do them, normal because others justify them. Behaviors that become normal because as a whole the responsibility has been distributed, automatized, and organized. But perhaps more importantly, because by normalizing, the organizational and social context demystifies social life as a distant fairytale, with its good vs bad, with its paladins vs monsters. The grays are much more interesting that the black and white metaphor of the "fight of the pure against the corrupt". 5

Denormalizing corruption is thus part of acting on the processes and routines that in practice are already established in an organization, deconstructing them in some form, with the purpose of understanding the casual social and argumentative chains that support them. Understand corruption as a social interaction makes it possible to study the rules of action, the group and psychological elements that incite and procreate behaviors that end up normalizing behaviors that derive into corruption.

Returning to the task at hand, it is required to advance on three fronts of denormalization (under the condition of not losing artificiality from sight): what individual characteristics lead to corruption? What organizational processes are generated in order to normalize corrupt acts? How are the processes and the organizational and institutional rules and regulations reinforced to position corrupt individuals or to make individuals become corrupt? In the moment that

\footnotetext{
5 One of the most serious obstacles in understanding corruption most likely has to do with the strength of the moralist and normative speeches that this concept awakens in contemporary societies. The concept of contemporary corruption is part of a dominant form of understanding modern society. On the basis of a definitive and clear separation of the public from the private, the most accepted concepts of corruption have to do with this ideal of the separation of two spheres of interests. When the private interest (legitimate in and of itself) negatively affects the public interest (likewise, legitimate, though much more abstract and closer to an ideal type), it is then that the maleficence of corruption appears. The public, pure, is adulterated by the inadequate interference (it is assumed that there is a possible, adequate interruption) of the private. This vision, which would be strange in "pre-modernity", always implies a normative definition of what makes "pure" the "public" and what makes said interference of the private, an inadequate interference. Without the myth and doctrine of "The King's Two Bodies" (Kantorowicz, 1957), these two bodies of every human being, the concrete and the abstract, the private and the public, the concept of contemporary corruption is impossible to understand. Part of the problem is thus in not being aware of the contradictions and limitations of the somewhat Manichaean vision of human beings in this normative framework, socially created in reality, from the separation between the public and the private. This normative and abstract idea, built social and historically (that of the separation of the public and the private) is, in turn, a political conceptualization that seeks to impose and normalize certain behaviors and ideas from a hegemonic framework that tries to establish what is "normal" (Bratsis, 2003, p. 17). However, it is the very illusion of purity of the public and the illusion of auto-control of the private to respect said purity, what probably makes us lose sight of just how corruption or the real behaviors of the people dealing with the artificiality of the spheres of the public and the private, are in themselves behaviors in social contexts, situations and logics.
} 
corruption is normalized, institutionalized, and becomes systemic in an organization or in a group of organizations, these three dimensions will be present recreating themselves.

\section{References}

Ackroyd, S., \& Thompson, P. (1999). Organizational misbehaviour. Londres: Sage. http://dx.doi.org/10.4135/ 9781446222232

Ainslie, G. (2001). Break-down of will. Cambridge: Cambridge University Press.

Anand, V., Ashforth, B., Joshi, M., \& Martini, P. (2004). Business as usual: The acceptance and perpetuation of corruption in organizations. Academy of Management Executive, 18(2), 39-55.

Andersson, S., \& Heywood, P. (2009). The politics of perception: Use and abuse of transparency international's approach to measuring corruption. Political Studies, 57, 746-767. http://dx.doi.org/10.1111/j.1467-9248.2008.00758.x

Arellano, D. (2010). Reformas administrativas y cambio organizacional: hacia el «efecto neto». Revista Mexicana de Sociología, 2010(2), 225-254.

Arellano, D. (2012). ¿Podemos reducir la corrupción en México? Límites y posibilidades de los instrumentos a nuestro alcance. México: CIDE.

Ashforth, B., \& Anand, V. (2003). The normalization of corruption in organizations. Research in Organizational Behavior, 25, 1-52. http://dx.doi.org/10.1016/S0191-3085(03)25001-2

Ashforth, B., Gioia, D., Robinson, S., \& Treviño, L. (2008). Re-viewing organizational corruption. Academy of Management Review, 33(3), 670-684. http://dx.doi.org/10.5465/AMR.2008.32465714

Bandura, A. (1990). Mechanisms of moral disengagement. In W. Reich (Ed.), Origins of terrorism: Psychologies, ideologies, theologies, states of mind (pp. 161-191). Cambridge University Press: Cambridge.

Bargh, J., \& Chartrand, T. (1999). The unbearable automaticity of being. American Psychologist, 54(7.), 462-479. http://dx.doi.org/10.1037/0003-066X.54.7.462

Benson, M. (1985). Denying the guilty mind: Accounting for involvement in a white-collar crime. Criminology, 23, 583-607. http://dx.doi.org/10.1111/j.1745-9125.1985.tb00365.x

Berger, P., \& Luckman, T. (1978). La construcción social de la realidad. Buenos Aires: Amorrortu.

Bratsis, F. P. (2003). The construction of corruption, or rules of separation and illusions of purity in Burgeo is Societies. Social Text, 71(21-4) http://dx.doi.org/10.1215/01642472-21-4 77-9, 9.33

Caiden, G., Dwivedi, O., \& Jabbra, J. (2001). Where corruption lives. Bloomfield: Kumarian Press.

Chibnall, S., \& Saunders, P. (1977). Worlds apart: Notes on the social reality of corruption. The British Journal of Sociology, 28(2), 138-154.

Chugh, D., Bazerman, M., \& Banaji, M. (2005). Bounded ethicality as a psychological barrier to recognizing conflicts of interest. In D. Moore, D. Moore, et al. (Eds.), Conflict of interest (pp. 74-95). Cambridge: Cambridge University Press.

Cialdini, R. B., Pterova, P. K., \& Goldstein, N. J. (2004). The hidden costs of organizational dishonesty. Sloan Management Review, 45, 67-73.

Conklin, J. (1977). Business crime in America. Englewood: Prentice-hall.

Costas, J., \& Grey, C. (2014). Bringing secrecy into de the open: Towards a theorization of the social processes of organizational secrecy. Organization Studies, 35(10), 1423-1447. http://dx.doi.org/10.1177/0170840613515470

Cressey, D. (1986). Why managers commit fraud. Australian and New Zealand Journal of Criminology, 19, 195-209.

Cyert, R., \& March, J. (1965). Teoría de las decisiones económicas de la empresa. México: Herrero.

Darley, J. (2001). The dynamics of authority influences in organizations and the unintended action consequences. In J. M. Darley, D. M. Messick, \& T. R. Tyler (Eds.), Social influences on ethical behavior in organizations (pp. 37-52). New Jersey: Erlbaum.

De Graaf, G. (2007). Causes of corruption: Towards a contextual theory of corruption. Public Administration Quarterly, $31(1-2), 39-86$.

De Graaf, G., Wagenaar, P., \& Hoenderboom, M. (2010). Constructing corruption. In G. de Graaf, P. von Maravic, \& P. Wagener (Eds.), The good cause. Theoretical perspectives on corruption (pp. 98-114). Opladen \& Famington Hills: Barbara Budrich Pub.

Eagleman, D. (2012). Incognito. The secrets lives of the brain. Nueva York: Vintage.

Felps, W., Mitchell, T., \& Byington, E. (2006). How, when, and why bad apples spoil the barrel: Negative group members and dysfunctional groups. Research in Organizational Behavior, 27, 175-222. http://dx.doi.org/10.1016/ S0191-3085(06)27005-9

Festinger, L. (1957). A Theory of cognitive dissonance. Stanford: Stanford University Press. 
Fleming, P., \& Zyglidopoulos, S. (2009). Charting corporate corruption. Northampton: Edward Elgar Pub.

Geis, G., \& Meier, R. (1979). The white-collar offender. In H. Touch (Ed.), Psychology of crime and criminal justice. Prospect Heights: Waveland Press.

Giddens, A. (1984). The constitution of society. Berkeley: University of California Press.

Gigerenzer, G. (2002). Bounded rationality: The adaptive toolbox. Cambridge: MIT Press.

Goffman, E. (1981). Forms of talk. Philadelphia: University of Pennsylvania Press.

Goffman, E. (1983). La presentación de la persona en la vida cotidiana. Buenos Aires: Amorrortu.

Haller, D., \& Shore, C. (2005). Corruption. Anthropological perspectives. Londres: Pluto Press.

Kantorowicz, E. T. (1957). The king's two bodies. Princeton: Princeton University Press.

Kish-Gephart, J., Harrison, D., \& Treviño, L. K. (2010). Bad apples, bad cases, and bad barrels: Metaanalytic evidence about sources of unethical decisions at work. Journal of Applied Psychology, 95(1), 1-13. http://dx.doi.org/10.1037/a0017103

Kunda, G. (1992). Engineering culture. Filadelfia: Temple University.

Lehrer, J. (2009). How we decide. Boston: Mariner Books.

Lerner, J., \& Tetlock, P. (1999). Accounting for the effects of accountability. Psychological Bulletin, 125(2), 255-275. http://dx.doi.org/10.1037/0033-2909.125.2.255

Lifton, R. (1986). The Nazi doctors: Medical killing and the psychology of genocide. Nueva York: Basic.

McLean, B., \& Elkind, P. (2004). The smartest guys in the room. Nueva York: Portfolio Trade.

Messick, D., \& Bazerman, M. (1996). Ethical leadership and the psychology of decision making. Sloan Management Review, 37(2), 9-22.

Milgram, S. (2005). Obedience to authority. Nueva York: Printer \& Martin [1974].

Mols, F., Haslam, A., Jetten, J., \& Steffens, N. (2014). Why a nudge is not enough: A social identity critique of governance by stealth. European Journal of Political Research, 54(1), 81-98. http://dx.doi.org/10.1111/1475-6765.12073

Nye, J. (1967). Corruption and political development: A cost benefit analysis. American Political Science Review, 61(2), 417-427.

Philp, M. (1997). Defining political corruption. Political Studies, 45(3), 436-462. http://dx.doi.org/10.1111/ 1467-9248.00090

Pinto, J., Leana, C., \& Pil, F. (2008). Corrupt organizations or organizations of corrupt individuals? Two types of organization-level corruption. Academy of Management Review, 33, 685-709. http://dx.doi.org/10.5465/ AMR.2008.32465726

Rest, J. (1986). Moral development: Advances in research and theory. Nueva York: Praeger.

Rose-Ackerman, S. (1978). Corruption: A study in political economy. Nueva York: Academic Press.

Rose-Ackerman, S. (2014). Corruption and conflict of interests. In J.-B. Auby, E. Breen, \& T. Perroud (Eds.), Corruption and conflict of interest. A comparative law approach (pp. 3-11). Cheltenham: Edward Elgar.

Simmel, G. (1906). The sociology of secrets and of secrets societies. American Journal of Sociology, 11(4), $441-498$.

Simon, H. (1947). Administrative behavior. Chicago: Chicago University Press.

Simon, H., Thompson, V., \& Smithburg, D. (2010). Public administration. Nueva York: Transaction Publishers [1950].

Sissener, T. (2001). Anthropological perspectives on corruption. pp. 5. Bergen: Chr. Michelsen Institute. WP.

Staub, E. (1989). The roots of evil: The origins of genocide and other group violence. Nueva York: Cambridge University Press.

Sykes, G., \& Matza, D. (1957). Techniques of neutralization: A theory of delinquency. American Sociological Review, 22, 664-670.

Turse, N. (2013). Killing everything that moves: The real American war in Vietnam. Nueva York: Picador.

Van Gennep, A. (1960). The rites of passages. Chicago: Chicago University Press.

Weick, K. (2001). Making sense of the organization. Oxford: Blackwell.

Zerubavel, E. (2006). The elephant in the room. Silence and denial in everyday life. Oxford: Oxford University Press.

Zyglidopoulos, S., \& Fleming, P. (2008). Ethical distance in corrupt firms: How do innocent bystanders become guilty perpetrators? Journal of Business Ethics, 78(172.), 4-5. http://dx.doi.org/10.1007/s10551-007-9378-4

Zyglidopoulos, S., Fleming, P., \& Rothenberg, S. (2009). Rationalization, overcompensation and the escalation of corruption in organizations. Journal of Business Ethics, 84(1), 65-73. http://dx.doi.org/10.1007/s10551-008-9685-4 